\title{
Salafi Women Resilience in Family Economic Fulfilment in Dieng Plateau
}

\author{
Sholihul Hakim ${ }^{1}$, Suwandoko², Muhammad Ardhi Razaq Abqa ${ }^{3}$, Sukron Mazid ${ }^{4}$ \\ \{sholihulhakim@untidar.ac.id ${ }^{1}$, suwandoko@untidar.ac.id², muhammadardhi@untidar.ac.id ${ }^{3}$, \\ sukronmazid@untidar.ac.id ${ }^{4}$ \}
}

\begin{abstract}
FISIPOL, Universitas Tidar, Jl. Kapten Suparman No.39, Tuguran, Potrobangsan, Kec. Magelang Utara, Kota Magelang, Jawa Tengah 56116 ${ }^{123}$. FKIP, Universitas Tidar, Jl. Kapten Suparman No.39, Tuguran, Potrobangsan, Kec. Magelang Utara, Kota Magelang, Jawa Tengah $56116^{4}$
\end{abstract}

\begin{abstract}
This research aims to identify Salafi women resilience and roles in family economic fulfilment. Salafi women resistance to limitations in society influences various aspects of social life. Their movement and scopes in daily life are quite limited. Salafi women have a meaningful role in economic activities in Dieng Plateau as prosperous family resistance. Low education level causes women workforce to work in non-formal sectors. Dieng Plateau society's activities are mostly in the agriculture and commerce sectors. This research applies descriptive qualitative with a case study approach. The result shows that Salafi women fulfil their family economic fulfilment for two purposes: Firstly, as the forms of participation to meet family economic needs by doing agriculture and commerce activity, secondly, as economic activity motivation to meet primary needs.
\end{abstract}

Keywords: Salafi Women, Economic Fulfillment,

\section{Introduction}

Indonesia is one of the world's biggest multicultural country with various ethnics, religions, races, and customs. Those diversities give Indonesia a unique national identity in the world as seen from various and broad socio-cultural and geographical conditions. ${ }^{[9]}$ Indonesia is also a country with diverse ethnics, cultural races, and beliefs. Choirul Mahfud stated that Indonesian has diverse language, social, culture, religion, political aspiration, and economic power. ${ }^{[7]}$

The democracy wave demands diversity admission in Indonesia, which has a plural life. Therefore, social diversity with all aspects of difference involved is the reality in life. Differences in social, economy, politic, and culture aspect are inavoidable. ${ }^{[1]}$ Multicultural education educates people to have sincere life, respect, and tolerate diverse culture in a plural society. ${ }^{[11]}$ In contrast to various cultures and religions, most Indonesian people are Muslim and use Pancasila as a fundamental principle. However, the increasing Muslim population in Indonesia becomes the target of hijrah activist and dakwah. Transnational Islam movement initiators campaign their movement to be massive movement in Indonesia. Transnational Islam has an ideological character focusing on the state-nation concept. However, the main focus lies on the religion ideology concept, which emphasizes on ummah togetherness path. This 
movement is dominated by fundamentalism scriptualist and transnational Islam movement, which partially adapt the modern idea.

Salafi women's activities are limited to the domestic area only, focusing on taking care of their children and obeying their husbands to be pious wives. They also become the teacher for their children while completing other household chores like cooking, washing, and taking care of their homes. Homes are the best place for her to reside and they must accept with no complaint. Salafi women do those duties in the form of compliance, obedience, respect, and piousness. All activities they do at home are not useless because Allah promises them merit if they do them patiently and sincerely. They can work away from home after they get permission and support from their husbands.[17]

According to Jannah, Salafi women prioritize four rules in their daily life. Women employment has indeed increased, as stated by Khotimah that data on women's participation in the labour market has increased significantly over the past decade. However, the percentage is small when compared to men. It indicates an increase in women's role, which is very significant in economic activities in Indonesia. However, the structure of the women workforce has low levels of education. Thus, most women still work in the informal sector or jobs which do not require high-quality knowledge and skills. From the gender perspective, the proportion of female and male workers in the informal sector consists of $40 \%$ women and $60 \%$ men. The proportion of female workers in the informal sector covers $70 \%$ of the total female workforce. ${ }^{[1]}$

Social and cultural changes and family economic needs fulfilment impact the Salafi women to help their husbands as family economy fulfilment. Salafi women living in the Dieng Mountains are very compliant and obedient to their husbands and they also do not hesitate to work to support and help their husbands with family needs. Even though the husband's position is higher, being imam and being the family head who is responsible both physically and mentally for the family. In fact, Salafi women or wives do not hesitate to help their husbands by farming in the fields and trading as most people in Dieng plateau area do.

In the public sphere, Salafi women tend to distance themselves from their social environment. So, the interaction of Salafi women with the community in their neighbourhood is quite limited. This is why Salafi women become exclusive or withdraw themselves from social interaction in the communities where they live. ${ }^{[16]}$ Unlike the Salafi women in general who have been mentioned above, the Kepakisan Salafi women living in Dieng plateau who are Javanese also work away from home. Salafi women in Kepakisan can still negotiate related to social activities, even to a job is not so self-limiting. However, some things cause Salafi women to avoid it since those violate sharia, like social interaction within the society who are not their mahram.

Salafi families communities implement several activities like agriculture, commerce, community social activities (kenduren, takziyah (condolences), seeing births, etc.). In agriculture, activities ranging from planting, plant tending, and harvesting agricultural products are also done. The clothes which show their identity are always worn by them in doing their activities in the fields. The same things apply in commerce activities; salafi women do it, although they still have to fulfil other household obligations. Salafi women in Kepakisan vary widely economically, many of whom fall into the category of economically weak families. Economically weak Salafi families will get assistance from both central and local governments and assistance from the village.

Research on Salafi is interesting to be observed and developed further. This research was initiated from the development of research by novice higher education lecturers in 2019 regarding the gender equality of Salafi families in Dieng Plateau written by Sukron Mazid and Sholihul Hakim. Furthermore, the researchers developed the resilience of Salafi women more 
broadly in fulfilling the family economy. The researches about Salafi have been done previously from a different point of view. The result of those researches are as follows:

Table 1. The review of relevant results

\begin{tabular}{ccl}
\hline Researchers & Year & \multicolumn{1}{c}{ Title } \\
\hline Krismono & 2015 & $\begin{array}{l}\text { Ekonomi-Politik Salafisme di Pedesaan Jawa (Studi } \\
\text { Kasus di Desa Kepakisan Kecamatan Batur } \\
\text { Kabupaten Banjarnegara) (The Political Economy of } \\
\text { Salafism in Rural Java (Case Study in Kepakisan } \\
\text { Village, Batur District, Banjarnegara Regency)) } \\
\text { Contesting Religious Authority, A Study on Dakwah } \\
\text { radio in Surakarta, Indonesia } \\
\text { Being Pious Among Indonesian Salafists," Al } \\
\text { Jami'ah: Journal of Islamic Studies } \\
\text { Peran Perempuan Salafi dan Kesejahteraan sosial } \\
\text { (The Role of Salafi Women and Social Welfare) } \\
\text { Kesetaraan Gender Keluarga Salafi di Pegunungan } \\
\text { Dieng (Gender Equality of Salafi Family in Dieang } \\
\text { Plateau) }\end{array}$ \\
Ahmad Bunyan & 2015 & 2017 \\
Taryamah
\end{tabular}

From some of the descriptions and backgrounds above, salafi women in fulfilling family needs need to be made into an in-depth study. The urgency is how Salafi women resist meeting the family's economic needs. Salafi women's resilience is carried out by helping their husbands as imam to support and help the family economy fulfil their daily needs. The social society tends to be exclusive but helps the family economy become compliance and obedience as a pious wife. Therefore, this research focuses on how the general description and how the Salafi women's resilience in Dieng plateau work to meet family needs, especially for Salafi in Kepakisan village, Batur district Banjarnegara regency.

\section{Methodology}

This research applied descriptive qualitative. Qualitative research is a series of practices in interpreting material from various representations, including various field notes, interviews, conversations, photos, recordings, and information-giving notes ${ }^{[1]}$ Ethnographic method was used in this research to explain the relationship between categories. Endraswara (2015) stated that ethnography is a study of society's life and culture ${ }^{[3]}$ The research was done in Kepakisan, Batur, Banjarnegara Regency from February to September 2020. The purposive sampling was used in this research and it was adjusted to the research's objectives. ${ }^{[12]}$ Research subjects were determined based on the person who is considered to know the most about the required information. This research subjects were the head of Kepakisan village, Elin, Lina, Ummu Fafa, Mrs. Torasmi, Ummu Imaroh, Tatik, and Mrs. Mulyati. The data collection techniques used in this research were in-depth interview, observation and document study. The researcher was the primary research instrument. The researcher was also the planner who determined the research's focus, selected informants, collected the data, interpreted the data, drew temporary conclusions, and analyzed it. ${ }^{[2]}$ This research applied the triangulation of technique and source to test the validity of the data. The data were then analyzed using data analysis by Miles and Huberman (1984), such as data reduction, data categorization and unitization, data display, and conclusion drawing verification. ${ }^{[10]}$ 


\section{$3 \quad$ Finding and Discussions}

\section{Forms of Family Economic Activity Participation}

Dieng Plateau is one of the mountain ranges with majority livelihood as a farmer. It has a mountain landscape in which the northern part borders with Batang Regency, the eastern part borders with Wonosobo regency, and the southern part borders with Banjarnegara Regency. The particular plant which becomes the primary income for Dieng farmers is potato. It is the primary commodity with the fastest income potent in 100 days and has the most profit potent. It is not surprising that there are many wealthy societies in Dieng and can do umrah and hajj more than once. Besides, house and mosque buildings and vehicles owned by Dieng society represent their prosperity.

Dieng society's farming activities are conducted either by men or women. In the morning, many women bringing farming tools can be seen along the route to Dieng. Salafi and non-Salafi women, involved in farming activities from morning until before Zhuhr and continued after Zhuhr until before Ashr, can also be seen in Kepakisan. Beside agriculture, some commerce can be found in Dieng like cake selling the business, food catering business, Carica home industry, vegetable brokers (calo), tour guides, tailoring services and courses.There are four main economic activities undergone by Salafi women: agriculture, commerce, convection, and farm labour.

\section{Agriculture}

The Salafi women like Elin, Ummu Imaroh, dan Mrs. Torasmi always go to the field every morning to tend the plants which become their main source of income either in the short or long term. Among those plants is potato, which needs 100 days to harvest, and it is their main commodity. Salafi women do all processes like planting, weeding, watering, fertilizing, and harvesting. As part of national development, the agricultural sector has a crucial role. This sector may absorb the most human resources or workforce and become the source of Indonesian society's livelihood in general. ${ }^{[13]}$ During interview, Mrs; Torasmi states: "When I go to the field, I plant potatoes, carrots, scallions, Bandung chilli (cabe bandung), carica, and dieng nuts. Everyday I go to the field for plant tending (removing the grass and adding soil for stem strengthening), spraying, watering during the drought, and harvesting".

The swiftness and agility of Salafi women in Kepakisan of Dieng Plateau show that they are diligent and energetic in assisting their husbands in earning money for family physiological needs fulfilment. Besides, some women also sell carica products by distributing them to the stores around Dieng as the food souvenirs like Mrs. Elin. Despite their exclusive nature for blending in their community, Salafi women are not clumsy to participate in family economic fulfilment. Besides, they are able to work well as forms of compliance and obedience to their husbands who permit while maintaining not to break the sharia in doing every activity.

\section{Commerce}

Mrs. Tatik prefers different economic activity compared to her friends, who are still active in the farming field. Since her marriage around 15 years ago in her house, she started her business, which is situated at the roadside. Her shop, which provides various daily needs like rice, frying oil, sugar, gas, and many others, are visited by many buyers. Her shop also provides snacks for kids, farming needs like fertilizers, fuel, gloves, hoes, farming hats, and masks. It also provides clothes for kids and ummahat annually like abaya, hijab, and niqob. She is able to earn a net income for 5-10 million each month. "I do not have other things to do except doing business. My husband and the workers have handled field activities. Besides, the field is not so large that it only requires a few people to work. My activities only include shopping in the 
market, looking after my children, cooking, and selling daily needs. No more than that." Salafi women are energetic and diligent in helping the family economy. It is exceptional for Salafi women despite their limited social interaction. Salafi women in Kepakisan of Dieng Plateau still participate in assisting family economic fulfilment. In addition to farming activities, commercial activities also function as Salafi women's effort to bring their families to prosperity while also requires their husband's permission.

\section{Service (Convection and Course)}

Bengzulu, who has hijroh name of Ummu Fafa, owns a sewing business and course. She established this business after graduating from SMKK Purworejo in 1987. Ummu Fafa accepts sewing orders for men, women, and children clothes. For women and children, she is able to determine the dimension by herself. Simultaneously, for men clothes, she can be assisted by her husband or customers bring the clothes sample as the fundamental dimension. She is able to complete approximately 30 clothes for each month, but during Lebaran her orders exceed, which require additional workers to complete them. "I sewed after graduating because I cannot continue to my study in university. After my marriage, I continue the sewing business and course at home assisted by some workers and my husband if the orders exceed the usual order" This sewing business, along with the short course for four months, are conducted at her home. The course participants are from various villages; this program is held annually. The learning materials given are designing the pattern, cutting the cloth, sewing the clothes, sewing the buttons, making the collar, and making men, women, and children clothes.

\section{Farm Labor}

Mrs. Mul, does her economic activity by working as farm labour in someone's field. Everyday she goes to the field in the morning to work on her employer's land like planting, applying fertilizer, weeding, spraying and watering, and harvesting. She works from 08.00 until 13.00 for a daily payment of Rp. 30.000-. If she has finished the job there, she continues other collective work with her group, who always accept collective work. These collective workers have different groups, male groups and female ones.

\section{Motivation of Economic Activity}

Poverty is the most crucial problem in Indonesia. These conditions demand the action to change into the expected better condition. The economy in the family can be illustrated as fuel to empower the car. Many families experience disharmony due to an unhealthy economy. Most of them work overnight only to fulfil the physiological need for material needs.

According to Maslow's need theory, something possessed by Kepakisan society since converting from tobacco into potato plant is an act to meet the feeling of safety, free from cold air, access or distance and workload can be reduced by owning motorized vehicle at home. While according to motivation theory, their actions are an effort to change into better conditions. Elin's family clearly shows that they save their sale and agriculture income to buy concrete bricks and keep them besides their house to repair their house. "My husband and I work hard to meet our economic needs, daily needs, and to get a better life than now". Maslow classified five levels of humans' needs. Those are Physiological Needs, Safety Needs, Social Needs, Self Esteem Needs, and Self Actualization. ${ }^{[8]}$ Four out of five levels of human needs are found in Salafi women's motivation for working in agriculture, commerce, sewing business, and farm labour: Physiological Needs, Safety Needs, Social Needs, and Self Actualization. 


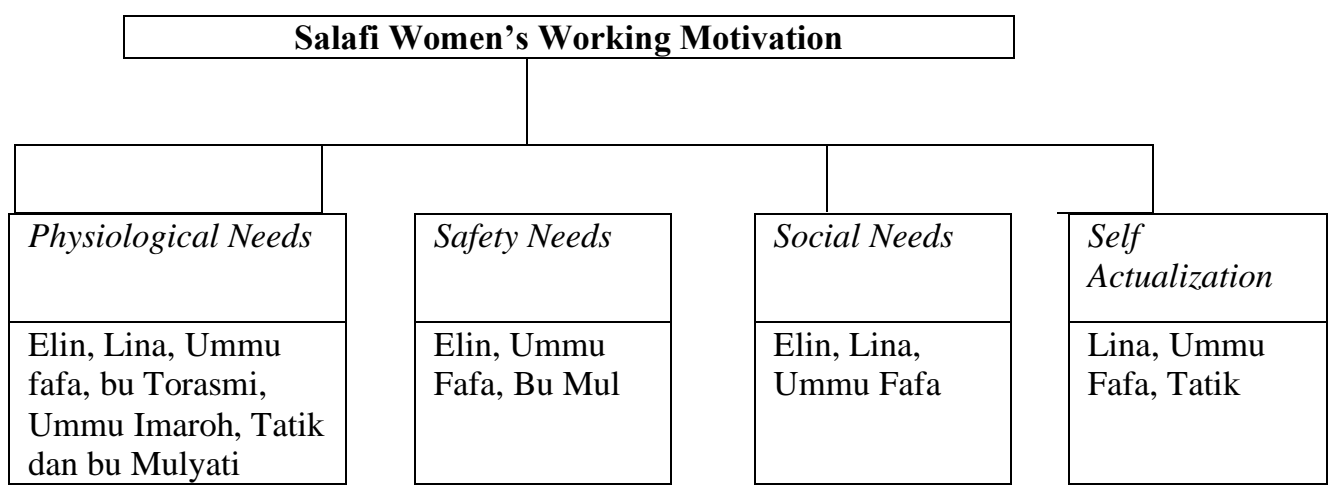

Notes: Salafi Women's Working Motivation in Kepakisan

Figure 1. Maslow's Motivation Theory

\section{To Meet Physiological Needs}

In doing economic activities, Elin, Lina, Ummu Fafa, Mrs. Mul, Mrs. Torasmi, Ummu Imaroh and Tatik can be categorized to meet Physiological Needs. Elin's statement proves it: "I sell snacks for kids, carica products, and assist husband at the field to meet physiological needs, like kitchen, children's money, education and unexpected needs like health and relative visit in other regions. "It is common for families with toddlers to spend money when their children ask money to buy snacks or suddenly get sick. Besides, these women also use some of their trading earnings for societal activities like selapanan (commemorate birthdays after 35 days) fee, foundation or Islamic boarding schools fee, and physiological needs.

Mariam, Imaroh, Mrs. Torasmi and Lina use their agriculture income to meet their primary needs. The income is divided into several purposes like kitchen purpose, social purpose, health purpose, education purpose, and house and vehicle maintenance purposes. They consider education purpose along with house and vehicle maintenance purposes as safety needs. Unlike her other three friends, Tatik uses her commerce income to meet physiological needs like kitchen, electricity, and social rituals.

While Mrs. Mulyati becomes farm labour and family head due to her husband's severe sickness and inability to earn money for his family. The money she earns from daily and collective labour is used to meet family primary needs, her husband's health and her son's education needs who still studies in SMK Islam Wonosobo. She also receives a governmental scholarship for the low-income family through Smart Indonesia Card (KIP) and Family Hope Program (PKH) for her son's educational needs. These guarantee Mrs. Mul's safety needs, which enable her to allocate her income for house rent and eating needs. Ummu Fafa uses her sewing business income to meet kitchen needs and unexpected social needs. She is ready for any unexpected expense thanks to her financial ability in managing her husband's salary.

\section{Safety Needs}

The researcher found that most people keep building materials like rocks, concrete bricks, window or door frames, and zinc roofs around their houses. Elin, whose house and building materials also surround the fence, explains, "My husband and I gathered the materials from our agriculture income to repair our house. Because we are unable to build the house directly, so we save the materials little by little until the expected amount to renovate our house gathered." Elin 
set allocation from daily needs until unexpected needs. She spends the agriculture income for long-term needs like building materials for a house renovation, vehicle maintenance, and a regular mosque. These needs can be categorized as safety needs. Saving building material for the house renovation is useful, so the materials are ready to use whenever the house needs renovation. Ummu Fafa applies different management in money-saving. This saving is the safety needs of her children education in other cities. Similarly, Mrs. Mul also allocates her income for her son's education and husband's health. She created a moneybox (a container to save money) each time she gets a salary from her daily and collective work.

\section{Affection (Social Needs)}

The social needs are reflected in Elin, Lina, and Ummu Fafa. "One of my reasons for working to assist my husband is because he loves his family. He earns money and always prioritizes us as his family I'd like to help him maintain his love and care for his family. " Elin does business at home and helps his husband in the field to maintain harmony in her family. Communication during activities in the field can be used as a sharing medium. Husband's attention and response toward Elin's business activity and assistance in the field are Elin's social needs in her married life with his husband. Lina and Ummu Fafa also share a similar idea. They always get attention from their husband as well as their relatives and neighbours. This is the impact of local culture, like helping each other either in happiness or sadness. They always allocate their business earning to help their neighbours through BAZ and Orphans foundation collected through selapanan. The existing social solidarity in society is increasing due to the establishment of the zakat organization. This is the form of social needs which unite both economically strong society and the economically weak ones.

\section{Self Actualization (Actualization Needs)}

Ummu Fafa's sewing skills and course are used to fulfil physiological needs and fulfil her self-actualization needs. Her sewing skills will not vanish and can be beneficial for surrounding societies who need their skills. Salafi women in Kepakisan participate in economic activities as inspired by R.A. Kartini's struggle which resulted in role, position, and natural distribution for masculine and feminine are not permanent, but interchangeable instead. ${ }^{[15]}$ They are also inspired by some wives of Prophet Muhammad's companion (sahaba) who also participate in economic activities and work in a public area. Some of them are Al Syifa whom Umar bin Khattab appointed as market manager in Madinah, Zainab and Asma' who left home to help their husbands earning money. Salafi women in Kepakisan help their husband in economic activities "are not due to desire and position". They only intend to give their best efforts to help their husbands as far as they can. Most of them become the breadwinner instead.

\section{Salafi Women Resistance in Economic Needs Fulfillment}

Their activities at home and field are not new things for them, but daily habit instead. Their husbands have supported them to do economic activities as they ask permission from them and obeying several conditions. In doing their economic activities, Salafi women must obey four compulsory conditions like; following hajjah (sharia of Islam), when they have reached syafar limitation (long-distant traveling and requires preparation like finance, clothes, logistic, etc), they must be accompanied by Mahrom (sister or brother), not intended for position desire, and maintaining silaturahmi. They must follow sharia of Islam like covering aurat by wearing niqob, abaya, gloves, socks, and must be in dark colour without any painting decoration on the cloth. They must lower their vision, reduce their voice volume, avoid excessive dressing style (tabarruj), and maintain their attitude.

They have to separate themselves from non-mahram people in doing their activities. These are mainly to avoid fitna when they are away from home. Their economic activities are not done around Dieng area only. Nevertheless, they still intend to help their husbands earning 
money, not for worldly position desire. Although wives' incomes are more than their husband's, they must stay loyal to their family and must not have a desire for praise. Salafi women must not think that they are stronger and better than their husband. They must keep in mind that their husband are their imam and leaders in their families who still have to earn money for their wives and children.

According to Salafi people, they are not allowed to do silaturahm with kafir harbi. Kafir harbi are those who interrupt, endanger, invade, and cause disadvantage. They also believe that silaturahm is one of the ways to invite rizq. Although they use Salafi as their guidance (qibla) various Salafi strict rules are not convenient to apply when doing activities away from home. Domestication, which becomes the ideal concept for Salafi women, has been negotiated and enables it to be more flexible to blend with local tradition. This is visible in Salafi Javanese women in Kepakisan village. The local tradition approach provides convenience for working activities and social activities that have existed for a long time because its strict exclusiveness results in stiffness and failure, which makes it hard for Salafi dakwah to continue.

\section{Conclusion}

Based on the research results and discussion elaborated previously, it can be concluded that Salafi women resistance to family economic fulfilment is for life survival. They can work well as the forms of their compliance, obedience, and piousness to their husbands. They must acquire their husbands' permission before conducting social and economic activities and try not to break sharia in their activities. Salafi women have two reasons for their economic family fulfilment: Firstly, they work in farm, commerce, service, and labour as the forms of economic family participation. It is purely as the forms of compliance, obedience, and piousness to their husband as to the imam (leader) whom they have to obey without breaking religion sharia. Secondly, to fulfil primary needs, economic motivation is to get safety, mercy, or selfactualization. Salafi women's economic motivation is to assist their husbands and not because of their worldly desires. They must cover their aurat and attitude based on Salaf teachings. Salafi women are attentive to their families by assisting their family economic fulfilment in realizing family prosperity.

\section{References}

[1] Creswell, J.W. Research design: Qualitative, quantitative and mixed methods approaches: Fourth edition. Thousand Oaks, CA: Sage Publications. 2014.

[2] Djaelani, A.R. Teknik pengumpulan data dalam penelitian kualitatif. Majalah Ilmiah Pawiyatan, 20 (1), (2013): 82-92.

[3] Endraswara, Suwardi. Etnologi Jawa Penelitian Perbandingan, dan Pemaknaan Budaya, Yogyakarta: Center of Academic Publishing Services. (2015).

[4] Jannah, Anas Shoff'aul. Konstruksi Identitas Kolektif Perempuan Gerakan Salafi (Studi di Masjid Ibnu Sina Fakultas Kedokteran UGM Yogyakarta). Jurnal Sosiologi Agama, 5 (2), (2013).

[5] Khotimah, K. Diskriminasi gender terhadap perempuan dalam sektor pekerjaan. Yinyang: Jurnal Studi Islam Gender dan Anak, 4 (1), (2009): 158-180.

[6] Mahanani, P. A. Rizqi Praktik Kekerasan Simbolik dalam Pemaknaan Perempuan Bekerja Menurut Manhaj Salafi. Ri'ayah: Jurnal Sosial dan Keagamaan, 2 (01), (2017): 180-198.

[7] Mahfud, Choirul. Pendidikan Multikultural. Yogyakarta: Pustaka Pelajar. 2014. 
[8] Maslow, Abraham H.. A Theory of Human Motivation. Psychological Review, 50(4), (1943): 370-396.

[9] Mazid, Sukron \& S. Suharno. Implementasi nilai-nilai multikultural dalam pembelajaran PKn. Harmoni Sosial: Jurnal Pendidikan IPS, 6 (1), (2019): 72-85.

[10] Miles, M. B., \& A. M. Huberman. An expanded sourcebook : Qualitative data analylis. (2ed ed). London : SAGE Publications. 1984.

[11] Muslimin. Pendidikan multikultural sebagai perekat budaya nusantara: menuju Indonesia yang lebih baik. Proseding seminar internasional multikultural \& globalisasi : Universitas Negeri Gorontalo. 2012.

[12] Sugiyono. Metode penelitian pendidian:Pendekatan kuantitatif, kualitatif, dan R\&D. Bandung: Penerbit Alfabeta. 2013.

[13] Wijayanti, Mila dan Samsul Ma'rif. Peran Kota-Kota Kecil Dalam Peningkatan Aktivitas Pertanian di Kawasan Agropolitan Merapi Merbabu. Teknik PWK (Perencanaan Wilayah Kota), 6 (3), (2017): 180-190.

[14] Zamroni. Pendidikan untuk demokrasi : Tantangan menuju civil society. Yogyakarta : Bigraf Publishing. 2001.

[15] Karlina, Yeni. "Dekonstruksi Stereotip Perempuan Dalam Sinetron Komedi SuamiSuami Takut Istri," 2009. http://thesis.umy.ac.id/index.php?opo=bibliography\&id $=41538$.

[16] Anas Shoff'aul Jannah, Konstruksi Identitas Kolektif Perempuan Gerakan Salafi, (2013).

[17] P.A. Rizqi Mahanani, Praktik Kekerasan Simbolik dalam Pemaknaan Perempuan Bekerja Menurut Manhaj Salafi. Ri'ayah: Jurnal Sosial dan Keagamaan, 2 (01), (2017): 180-198. 